Dan Longrois MD PhD, *

Emmanuel de Maistre MD, $\dagger$

Nicolas Bischoff MD, $\ddagger$

Christian Dopff MD, *

Claude Meistelman MD, *

Michaël Angioï MD, $\mathfrak{S}$

Thomas Lecompte MD $†$
Recombinant hirudin anticoagulation for aortic valve replacement in heparin-induced thrombocytopenia

Purpose: To report the case of a patient with HIT that received a prolonged infusion of $r$-hirudin (lepirudin; Refludan ${ }^{\circledR} ;$ Hoechst, France) before, during and after cardiopulmonary bypass (CPB) for aortic surgery. Although administration of $r$-hirudin for CPB anticoagulation has previously been reported, many questions persist concerning the best therapeutic regimen for CPB anticoagulation as well as the time of onset and the doses for postoperative anticoagulation.

Clinical Features: A 65-yr-old man was admitted for surgery of aortic stenosis after an episode of acute pulmonary edema complicated by deep venous thrombosis in the context of documented HIT. The patient received r-hirudin for 13 dy before surgery at doses $\left(0.4 \mathrm{mg} \cdot \mathrm{kg}^{-1}\right.$ bolus followed by $0.15 \mathrm{mg} \cdot \mathrm{kg}^{-1} \cdot \mathrm{hr}^{-1}$ continuous infusion) that maintained activated partial thromboplastin time (aPTT) ratios between 2 and 2.5. Anticoagulation for CPB was performed with r-hirudin given as $0.1 \mathrm{mg} \cdot \mathrm{kg}^{-1} \mathrm{iv}$ bolus and $0.2 \mathrm{mg} \cdot \mathrm{kg}^{-1}$ in the CPB priming volume. Anticoagulation during CPB was monitored with the whole blood activated coagulation time and ecarin clotting time (ECT) performed in the operating room with values corresponding to r-hirudin concentrations $>5 \mu \mathrm{g} \cdot \mathrm{m}^{-1}$ during CPB. Anticoagulation during CPB was uneventful. Two bleeding episodes, related to the r-hirudin regimen and necessitating allogeneic blood transfusion, occurred after surgery.

Conclusion: This case report confirms previous experience of the use of $r$-hirudin for anticoagulation during CPB and provides additional information in the context of prolonged $r$-hirudin infusion before and after CPB.

Objectif : Rendre compte du cas d'un patient qui présentait une TIH et qui a reçu une perfusion prolongée de r-hirudine (lépirudine; Refludan ${ }^{\circledR}$; Hoechst, France) avant, pendant et après la circulation extracorporelle (CEC) lors d'une intervention chirurgicale aortique. L'administration de l'anticoagulant $r$-hirudine pour la CEC est un fait connu, mais de nombreuses questions persistent sur le meilleur schéma thérapeutique à utiliser pendant la CEC et, sur le délai d'installation de l'anticoagulation et sur les doses à respecter après l'opération.

Éléments cliniques : Un homme de 65 ans a été admis pour l'opération d'une sténose aortique survenue après un épisode d'œè̀me pulmonaire aigu compliqué d'une thrombose veineuse profonde dans le contexte d'une $\mathrm{TIH}$ connue. Le patient a reçu de la r-hirudine pendant I 3 jrs avant l'intervention (bolus de $0,4 \mathrm{mg} \cdot \mathrm{kg}^{-1}$ suivi d'une perfusion continue à $0,15 \mathrm{mg} \cdot \mathrm{kg}^{-1} \cdot \mathrm{hr}^{-1}$ ) pour maintenir les ratios de temps de céphaline activé entre 2 et 2,5 (aPTT). Pendant la CEC, l'anticoagulation a été réalisée avec de la $r$-hirudine administrée en bolus de $0,1 \mathrm{mg} \cdot \mathrm{kg}^{-1}$ iv et $0,2 \mathrm{mg} \cdot \mathrm{kg}^{-1}$ dans le volume d'amorçage de la CEC. Elle a été contrôlée avec les test du temps de coagulation activé du sang complet et du temps de coagulation de l'écarine (TCE) réalisés dans la salle d'opération selon des valeurs qui correspondent à des concentrations de $r$-hirudine $>5 \mu \mathrm{g} \cdot \mathrm{ml}^{-1}$. Aucun incident n'a marqué la CEC, mais deux épisodes de saignement, reliés à l'usage de $r$-hirudine et nécessitant une transfusion de sang allogénique, sont survenus après l'opération.

Conclusion : Cette observation ajoute à l'expérience antérieure de l'usage de r-hirudine pour l'anticoagulation pendant la CEC et fournit des renseignements supplémentaires dans le contexte d'une perfusion prolongée de $r$ hirudine avant et après la CEC.

From the Department of Anesthesia and Intensive Care, ${ }^{\star}$ Department of Hematology, $\dagger$ Haemostasis Unit, Department of Cardiovascular Surgerył and Department of Cardiology, $\$ \mathbb{C H U}$ Nancy-Brabois, Vandoeuvre-les-Nancy, France.

Address correspondence to: Dan Longrois MD PhD, Department of Anesthesia and Intensive Care, CHU Nancy- Brabois, 4, rue du Morvan 54500 Vandoeuvre les Nancy, France. Phone: 33-3-83-15-41-66; Fax: 33-3-83-15-36-88; E-mail: d.longrois@chu-nancy.fr Accepted for publication November 27, 1999 
$\mathrm{H}$ IRUDIN is a natural peptide initially extracted from the salivary glands of leeches (Hirudo medicinalis) and recently produced by recombinant DNA technology in yeast (Saccharomyces cerevisiae). Unlike heparin, hirudin is a specific and cofactor-independent thrombin inhibitor and is not neutralized by plasma components or platelet-secreted proteins such as platelet factor -4 .

Recombinant hirudin ( $r$-hirudin) has been used in the clinical setting for anticoagulation after acute myocardial infarction, ${ }^{1}$ coronary angioplasty, ${ }^{2}$ prevention of deep venous thrombosis ${ }^{3}$ and cardiac surgery with cardiopulmonary bypass $(\mathrm{CPB})$ as an alternative to heparin..$^{4,5}$

Although administration of r-hirudin for CPB anticoagulation has previously been reported, many questions persist concerning the use of r-hirudin as a substitute for heparin in patients with heparin-induced thrombocytopenia (HIT) undergoing cardiac surgery. They are related to the optimal therapeutic regimen for $\mathrm{CPB}$ anticoagulation as well as the time of onset and the doses for postoperative anticoagulation.

We report a patient admitted for aortic valve replacement with concomitant heparin-induced thrombocytopenia in whom $\mathrm{r}$-hirudin was used for anticoagulation before, during and after cardiac surgery for 20 days.

Case report

A 65 -yr-old caucasian man weighing $78 \mathrm{~kg}$ was admitted to a primary care hospital for acute pulmonary edema caused by decompensated aortic valve stenosis. Left ventricular ejection fraction was $30 \%$ and pulmonary arterial hypertension was present. Anticoagulation with unfractionated heparin was started on the day of admission (Day 0) followed by low molecular weight heparin (Day 4). The platelet count decreased from $160 \mathrm{G} \cdot \mathrm{L}^{-1}$ on Day 0 to a nadir of $19 \mathrm{G} \cdot \mathrm{L}^{-1}$ on Day 14 with concomitant disseminated intravascular coagulation (fibrinogen level decreased to $1.2 \mathrm{~g} \cdot \mathrm{l}^{-1}$ ) which resulted in discontinuation of heparin therapy on Day 14. Both the platelet aggregation test and the ELISA with platelet factor-4/ heparin-coated plates (Diagnostica Stago, Asnières, France) were positive. ${ }^{6,7}$ Anticoagulation with danaparoid (Riom Laboratoires-Cerm, France) was begun on Day 15 at doses of 750 anti-Xa units bid $s c$ but was discontinued on Day 16 because the patient developed right femoral and iliac vein thrombosis (DVT). The thrombotic complication was probably related to a $24 \mathrm{hr}$ delay between cessation of heparin administration and onset of danaparoid therapy. At that time (July 1998) the regimen for danaparoid in DVT prophylaxis consisted of two daily injections of $750 \mathrm{U}$ which is presently consid- ered to be too low a dose. In addition, at that time, danaparoid was not approved for clinical use in DVT complicating HIT in France. For these reasons, anticoagulation with r-hirudin (lepirudin, Hoechst, France) was begun on Day 16. Recombinant hirudin had recently been approved in Europe as therapy for patients with HIT complicated by thrombosis.

The r-hirudin anticoagulation regimen was initiated, as recommended by the manufacturer, with a bolus dose of $0.4 \mathrm{mg} \cdot \mathrm{kg}^{-1}$ followed by a continuous infusion started at $0.15 \mathrm{mg} \cdot \mathrm{kg}^{-1} \cdot \mathrm{hr}^{-1}$ and adapted to maintain the activated partial thromboplastin time (aPTT ) ratio between 2-2.5 (from Day 16 to Day 29). Platelet counts progressively increased to $155 \mathrm{G} \cdot \mathrm{L}^{-1}$ on day 24 and stabilized. Preoperative platelet count and aPTT values as well as the different anticoagulant therapy regimens are presented in Table I. Aortic valve replacement was delayed until Day 29 because the patient developed left upper lobe pulmonary infection that was successfully treated with antibiotics.

\section{Cardiopulmonary bypass}

The CPB circuit was primed with $500 \mathrm{ml}$ Ringer's lactate, $500 \mathrm{ml}$ hydroxyethylstarch 6\% (Hesteril ${ }^{\circledR}$, Biosedra, France) and $400 \mathrm{ml}$ sodium bicarbonate 14\% solution. Eight hundred milliliters of this mixture were replaced with three units packed RBCs because of preoperative anemia (hemoglobin: $9 \mathrm{~g} \cdot \mathrm{dl}^{-1}$ ). Cardiopulmonary bypass was conducted with a membrane oxygenator and non-pulsatile flow of 2-2.5 $1 \cdot \mathrm{min}^{-1} \cdot \mathrm{m}^{-2}$ adjusted to maintain mean arterial blood pressure between 60-100 $\mathrm{mm} \mathrm{Hg}$ and oxygen saturation of the $\mathrm{CPB}$ venous line $>75 \%$. Strict normothermia $\left(37^{\circ} \mathrm{C}\right)$ was maintained throughout $\mathrm{CPB}$. Myocardial protection was performed with continuous retrograde potassium-enriched warm blood cardioplegia. Aortic cross clamp time was $20 \mathrm{~min}$ and the total CPB time was

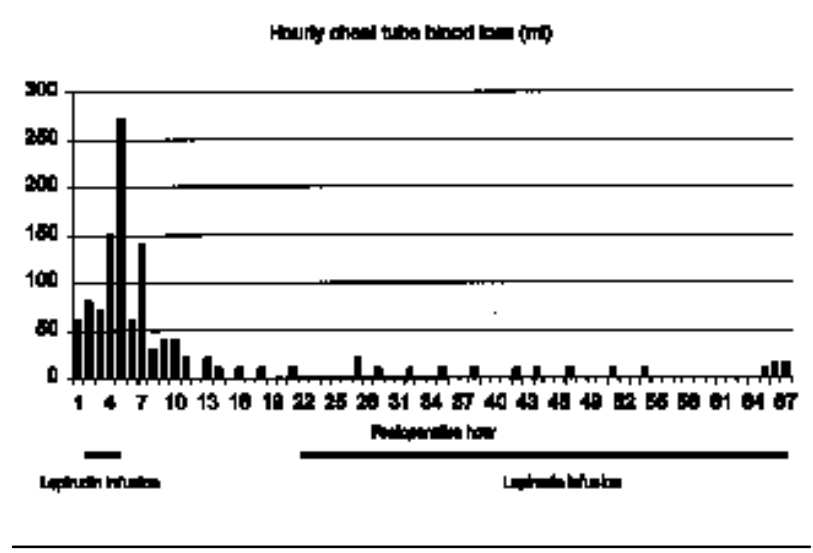

FIGURE Hourly chest tube blood loss (ml) 
30 min. Separation from CPB was uneventful and 5 $\mu \mathrm{g} \cdot \mathrm{kg}^{-1} \cdot \mathrm{min}^{-1}$ dobutamine was used for inotropic support. The trachea was extubated on the second postoperative day (Day 31). Cardiac, pulmonary, renal, and neurological functions were normal.

TABLE I Time course of platelet count and activated partial thromboplastin time

\begin{tabular}{llll}
\hline Time & Anticoagulation & $\begin{array}{l}\text { Platelet } \\
\text { count } \\
\left(G \cdot L^{-1}\right)\end{array}$ & $\begin{array}{l}\text { aPTT } \\
(\mathrm{sec})\end{array}$ \\
\hline Day 0 & Before UFH therapy & 160 & $\mathrm{ND}$ \\
Day 4 & Onset of LMWH therapy & 175 & $40 / 37$ \\
Day 11 & During LMWH therapy & 36 & $\mathrm{ND}$ \\
Day 14 & End of LMWH therapy & 19 & $43 / 37$ \\
Day 15 & Onset of danaparoid therapy & 23 & $\mathrm{ND}$ \\
Day 16 & $\begin{array}{l}\text { End of danaparoid therapy and } \\
\text { onset of r-hirudin therapy }\end{array}$ & 20 & $45 / 37$ \\
Day 20 & During r-hirudin therapy & 49 & $74 / 37$ \\
Day 22 & During r-hirudin therapy & 80 & $76 / 37$ \\
Day 24 & During r-hirudin therapy & 155 & $77 / 35$ \\
Day 29 & $\begin{array}{l}\text { Immediately after CPB } \\
\text { with r-hirudin }\end{array}$ & 53 & $62 / 37$ \\
\hline
\end{tabular}

UFH: unfractionated heparin; LMWH: low molecular weight heparin

CPB: cardiopulmonary-bypass

aPTT: activated partial thromboplastin time

ND: not done

Day 0 indicates the day of admission to the hospital.

Day 29 is the day of cardiac surgery

\section{Anticoagulation for cardiopulmonary bypass}

On the day of surgery, the r-hirudin continuous infusion $\left(0.1 \mathrm{mg} \cdot \mathrm{kg}^{-1} \cdot \mathrm{hr}^{-1}\right)$ was stopped after administration of a bolus of $0.1 \mathrm{mg} \cdot \mathrm{kg}^{-1}$ given $10 \mathrm{~min}$ before cannulation of the aorta. A dose of $0.2 \mathrm{mg} \cdot \mathrm{kg}^{-1}$ of $\mathrm{r}$-hirudin, was injected into the $\mathrm{CPB}$ priming volume. Anticoagulation was monitored with celite-based activated clotted time (ACT) (Hemochron ${ }^{\circledR}$, International Technidyne Corp., Edison, N.Y., USA) and citrated whole blood ecarin clotting time (ECT) (Ecarin, Diagnostica Stago, Asnières, France) performed in the operation room. The ECT was performed with a $\mathrm{KC} 10$ coagulometer (Amelung, Lengo, Germany) according to Pötzsch et al. ${ }^{8}$ Ecarin was reconstituted at a concentration of $16 \mathrm{U} \cdot \mathrm{ml}^{-1}$ with HEPES buffer in saline containing $0.025 \mathrm{~mol} \cdot \mathrm{l}^{-1}$ calcium chloride and was preincubated at 37 . Whole blood ECT was performed in duplicate by addition of $50 \mu \mathrm{l}$ ecarin solution to 100 $\mu \mathrm{l}$ citrated whole blood preincubated for one minute at $37^{\circ} \mathrm{C}$. A calibration curve was constructed using normal human whole blood spiked with r-hirudin to achieve final concentrations of $1,2,3$, and $4 \mu \mathrm{g} \cdot \mathrm{ml}^{-1}$ respectively. When necessary, the patient's whole blood was diluted with normal whole blood in order to achieve estimated hirudin concentrations within the measured range $\left(0-4 \mu \mathrm{g} \cdot \mathrm{ml}^{-1}\right)$. The therapeutic target of $\mathrm{r}$-hirudin concentration in whole blood was $>3.5 \mu \mathrm{g} \cdot \mathrm{ml}^{-1}$. Table II indicates the evolution of ACT and r-hirudin concentrations derived from ECT after r-hirudin bolus

TABLE II Time course of celite-based activated clotting time and ecarin clotting time for anticoagulation during cardiopulmonary bypass.

\begin{tabular}{|c|c|c|c|}
\hline Time & Doses of r-hirudin & $A C T(s e c)$ & $\begin{array}{l}\text { Hirudin concentrations } \\
\text { (ug. } \mathrm{mt}^{-1} \text { of whole blood) } \\
\text { derived from the ECT }\end{array}$ \\
\hline \multicolumn{4}{|l|}{ arrival in } \\
\hline operation room & continuous $\mathrm{r}$-hirudin infusion $0.1 \mathrm{mg} \cdot \mathrm{kg}^{-1}$ hourly & 290 & 3.3 \\
\hline 3 min after & & & \\
\hline r-hirudin bolus & r-hirudin $0.1 \mathrm{mg} \cdot \mathrm{kg}^{-1} i v$ bolus & 364 & 5.6 \\
\hline \multicolumn{4}{|l|}{3 min after } \\
\hline $\mathrm{CPB}$ onset & r-hirudin $0.2 \mathrm{mg} \cdot \mathrm{kg}^{-1}$ in the $\mathrm{CPB}$ priming volume & $>1200$ & 7.6 \\
\hline \multicolumn{4}{|c|}{ 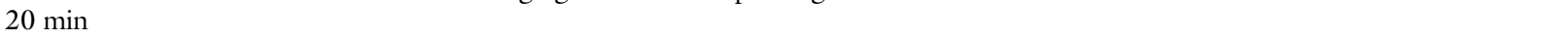 } \\
\hline during $\mathrm{CPB}$ & r-hirudin infusion stopped & 516 & 6.3 \\
\hline \multicolumn{4}{|l|}{$30 \mathrm{~min}$} \\
\hline during $\mathrm{CPB}$ & & 372 & 5.8 \\
\hline \multicolumn{4}{|l|}{10 min after } \\
\hline \multicolumn{3}{|l|}{20 min after } & 4.1 \\
\hline end of $\mathrm{CPB}$ & & 255 & 3.2 \\
\hline \multicolumn{4}{|l|}{30 min after } \\
\hline end of $\mathrm{CPB}$ & & 230 & 3 \\
\hline
\end{tabular}

ACT: activated clotting time (celite, Hemochron $\left.{ }^{\circledR}\right)$

ECT: ecarin clotting time

CPB: cardiopulmonary bypass 
TABLE III Time course of postoperative anticoagulant therapy

\begin{tabular}{|c|c|c|c|c|}
\hline Time & r-hirudin doses & $O A C$ & APTT/control (sec) & $I N R$ \\
\hline $\begin{array}{l}\text { day of surgery (Day 29) } \\
\text { (postoperative hour 1) }\end{array}$ & Before onset of r-hirudin infusion & & $62 / 37$ & \\
\hline $\begin{array}{l}\text { day of surgery } \\
\text { (postoperative hour 2) }\end{array}$ & $\begin{array}{l}\text { r-hirudin } \\
0.05 \mathrm{l} \mathrm{mg} \cdot \mathrm{kg}^{-1} \cdot \mathrm{hr}^{-1}\end{array}$ & & ND & \\
\hline $\begin{array}{l}\text { Day of surgery } \\
\text { (postoperative hour 6) }\end{array}$ & r-hirudin infusion stopped (hemorrhage) & & $73 / 37$ & \\
\hline $\begin{array}{l}\text { Postoperative Day l } \\
\text { (Day 30) }\end{array}$ & $\begin{array}{l}\mathrm{r} \text {-hirudin resumed } \\
0.05 \mathrm{mg} \cdot \mathrm{kg}^{-1} \cdot \mathrm{hr}^{-1}\end{array}$ & & $63 / 37$ & \\
\hline $\begin{array}{l}\text { Postoperative Day } 2 \\
\text { (Day } 31 \text { ) }\end{array}$ & $\begin{array}{l}\mathrm{r} \text {-hirudin } \\
0.05 \mathrm{mg} \cdot \mathrm{kg}^{-1} \cdot \mathrm{hr}^{-1}\end{array}$ & & $69 / 37$ & \\
\hline $\begin{array}{l}\text { Postoperative Day } 3 \\
\text { (Day } 32 \text { ) }\end{array}$ & $\begin{array}{l}\text { r-hirudin } \\
0.05 \mathrm{mg} \cdot \mathrm{kg}^{-1} \cdot \mathrm{hr}^{-1}\end{array}$ & $\begin{array}{l}\text { Onset of } \\
\text { fluindione } \\
\text { therapy }\end{array}$ & $65 / 37$ & \\
\hline $\begin{array}{l}\text { Postoperative Day } 4 \\
\text { (Day 33) }\end{array}$ & $\begin{array}{l}\text { r-hirudin infusion stopped } \\
\text { (hemorrahge) }\end{array}$ & fluindione & $57 / 37$ & \\
\hline $\begin{array}{l}\text { Postoperative Day } 5 \\
\text { (Day } 34 \text { ) }\end{array}$ & $\begin{array}{l}\mathrm{r} \text {-hirudin resumed } \\
0.05 \mathrm{mg} \cdot \mathrm{kg}^{-1} \cdot \mathrm{hr}^{-1}\end{array}$ & fluindione & $79 / 37$ & 1.8 \\
\hline $\begin{array}{l}\text { Postoperative Day } 6 \\
\text { (Day 35) }\end{array}$ & $\begin{array}{l}\text { r-hirudin } \\
0.05 \mathrm{mg} \cdot \mathrm{kg}^{-1} \cdot \mathrm{hr}^{-1}\end{array}$ & fluindione & $71 / 37$ & 1.9 \\
\hline $\begin{array}{l}\text { Postoperative Day } 7 \\
\text { (Day 36) }\end{array}$ & $\begin{array}{l}\mathrm{r} \text {-hirudin } \\
0.05 \mathrm{mg} \cdot \mathrm{kg}^{-1} \cdot \mathrm{hr}^{-1}\end{array}$ & fluindione & $93 / 37$ & 2.7 \\
\hline $\begin{array}{l}\text { Postoperative Day } 8 \\
\text { (Day } 37 \text { ) }\end{array}$ & - & fluindione & $58 / 37$ & 2.2 \\
\hline
\end{tabular}

OAC: oral anticoagulant

aPTT: activated partial thromboplastin time; INR: international normalized ratio

administration before, during and immediately after CPB. Because both ACT and ECT were above the recommended therapeutic targets for CPB anticoagulation with r-hirudin, ${ }^{9}$ no supplementary r-hirudin was given during CPB. There were no clinically detectable bleeding or clotting in the cardiopulmonary bypass circuit or in the operative field.

\section{Postoperative course and anticoagulation}

Blood loss through the chest tubes is presented in Figure 1. The r-hirudin infusion was resumed at the 2nd postoperative hour at a dose of $0.05 \mathrm{mg} \cdot \mathrm{kg}^{-1} \cdot \mathrm{hr}^{-1}$ (half the dose administered before surgery) because chest tube drainage was $<50 \mathrm{ml} \cdot \mathrm{hr}^{-1}$. Two hours after onset of r-hirudin infusion (4th postoperative hour), bleeding from chest tubes was $>100 \mathrm{ml} \cdot \mathrm{hr}^{-1}$. The $\mathrm{r}-$ hirudin infusion was stopped at the 5 th postoperative hour. The patient was transfused with nine units of packed RBCs and six units of fresh frozen plasma. The evolution of aPTT after surgery is presented in Table III. Anticoagulation with $\mathrm{r}$-hirudin was resumed as a continuous infusion of $0.05 \mathrm{mg} \cdot \mathrm{kg}^{-1} \cdot \mathrm{hr}^{-1}$ on the lst postoperative day (Day 30) without any increase in blood loss through the chest tubes (Figure) which were withdrawn on the 4 th postoperative day (Day 33 ).
Oral anticoagulant therapy with $5 \mathrm{mg}$ fluindione (vitamin $\mathrm{K}$ antagonist) QD was started on the 3rd postoperative day (Day 32). On the following day, the femoral artery catheter was removed and a left groin hematoma developed requiring surgical evacuation and temporary cessation of $\mathrm{r}$-hirudin infusion for $12 \mathrm{hr}$. One litre blood was evacuated and the patient received three units of packed RBCs. The r-hirudin infusion was stopped on the 7th postoperative day (Day 36) while INR were 1.9 and 2.7 on two consecutive measurements.

Discussion

This report provides additional evidence that, in selected patients, hirudin can be used as a substitute for heparin for anticoagulation during cardiopulmonary bypass. In addition, new elements concerning the management of such patients are reported. The patient received $\mathrm{r}$-hirudin for $13 \mathrm{dy}$ before cardiac surgery which is longer than previously reported. ${ }^{9}$ As a result, both ACT and ECT were prolonged before anticoagulation for bypass (see Table II). The rhirudin dose administered for $\mathrm{CPB}$ anticoagulation was $0.1 \mathrm{mg} \cdot \mathrm{kg}^{-1}$ which is half the recommended dose in humans given r-hirudin for CPB anticoagulation. ${ }^{9}$ This low r-hirudin dose resulted, before CPB onset, in 
ACT and ECT values above the recommended therapeutic targets for $\mathrm{CPB}$ anticoagulation (Table II). The r-hirudin dose administered in the CPB priming volume, based on a previously published report, ${ }^{9}$ seems relatively high because both ACT and ECT values in this case report were far above therapeutic targets just after CPB onset (Table II). This suggests that the $r$ hirudin dose injected in the $\mathrm{CPB}$ priming volume was responsible for the greatly increased ACT and ECT after CPB onset. Nevertheless, both ACT and ECT decreased after $\mathrm{CPB}$ onset but remained above the therapeutic targets without administration of supplemental $r$-hirudin. These observations are consistent with the relatively short $\mathrm{r}$-hirudin half-life (approximately one hour) in patients with intact renal function. ${ }^{10} \mathrm{~A}$ longer $\mathrm{CPB}$ time would have probably made supplemental r-hirudin administration mandatory, as reported previously. ${ }^{9}$ Our observations indicate that the published regimens of $r$-hirudin administration for $\mathrm{CPB}$ anticoagulation should be adapted in patients already receiving a continuous infusion of $r$-hirudin and that the current dose of $0.2 \mathrm{mg} \cdot \mathrm{kg}^{-1} \mathrm{r}$-hirudin in the $\mathrm{CPB}$ priming volume can result in transient excessive anticoagulation.

Monitoring $\mathrm{CPB}$ anticoagulation requires rapid results that allow immediate administration of additional doses of the anticoagulant drug. In this context, CPB anticoagulation with r-hirudin should be performed on whole blood tests such as ACT or ECT. A good linear relationship was demonstrated between the hirudin concentration and the ECT but not the ACT values. ${ }^{8}$ In addition, ECT values are not influenced by moderate hemodilution. Therefore, the use of ECT, despite limited experience, has been suggested for on-site monitoring of CPB anticoagulation with r-hirudin. ${ }^{8}$

Anticoagulation with $\mathrm{r}$-hirudin after cardiac surgery with r-hirudin-based CPB anticoagulation has been reported previously. ${ }^{9}$ Based on that report, and because of the short half life of r-hirudin, we started the continuous $r$-hirudin infusion on the 2 nd postoperative hour because chest tube blood loss was $<50$ $\mathrm{ml} \cdot \mathrm{hr}^{-1}$ although aPTT was prolonged (Table III). Postoperative blood loss (Figure) paralleled r-hirudin reintroduction in the immediate postoperative period whereas, on the first postoperative day, r-hirudin infusion was resumed without any effect on blood loss through the chest tubes. Therefore, we suggest that the reintroduction of r-hirudin as anticoagulant after cardiac surgery be dictated by both clinical (blood loss through the chest tubes) and laboratory data such as the ECT value.

In conclusion, this case report confirms previous experience with r-hirudin for $\mathrm{CPB}$ anticoagulation and demonstrates that r-hirudin can be used as a substitute to heparin in patients with heparin-induced thrombocytopenia. Our experience suggests that $r$ hirudin doses should be carefully titrated and that in patients already receiving a continuous infusion of $r$ hirudin lower doses can offer anticoagulation within the recommended therapeutic targets. Reintroduction of r-hirudin for postoperative anticoagulation should be delayed for several hours.

Acknowledgment

We would like to acknowledge the kind help of Dr. Bruno Besse (Laboratoires Hoechst Houdé, France).

\section{References}

1 Antman EM. Hirudin in acute myocardial infarction. Thrombolysis and thrombin inhibition in myocardial infarction (TIMI) 9B trial. Circulation 1996; 94: 911-21.

2 Cannon CP, Braunwald E. Hirudin: initial results in acute myocardial infarction, unstable angina and angioplasty. J Am Coll Cardiol 1995; 25: 30S-37S.

3 Agnelli G, Sonaglia F. Recombinant hirudin in the prevention of venous thromboembolism in patients undergoing elective hip surgery. Semin Thromb Hemost 1997; 23: 143-8.

4 Riess FC, Pötzsch B, Bader R, et al. A case report on the use of recombinant hirudin as an anticoagulant for cardiopulmonary bypass in open heart surgery. Eur J Cardiothorac Surg 1996; 10: 386-8.

5 Greinacher A, Völpel H, Janssens $U$, et al. Recombinant hirudin (lepirudin) provides safe and effective anticoagulation in patients with heparin-induced thrombocytopenia. A prospective study. Circulation 1999; 99: 73-80.

6 Nguyen P, De Maistre E, Cornillet-Lefebvre P, Regnault $V$, Lecompte T. Heparin-induced thrombocytopenia in France 1980-1998. Semin Thromb Hemost 1999; 25(Suppl1): 9-15.

7 Nguyen P, Lecompte T. Heparin-induced thrombocytopenia: a survey of tests employed and attitudes in haematology laboratories. Nouv Rev Fr Hematol 1994; 36: 353-7.

8 Pötzsch B, Madlener K, Seelig C, Riess CF, Greinacher A, Müller-Berghaus $G$. Monitoring of r-hirudin anticoagulation during cardiopulmonary bypass-assessment of the whole blood ecarin clotting time. Thromb Haemost 1997; 77: 920-5.

9 Riess F-C, Lower C, Seelig C, et al. Recombinant hirudin as a new anticoagulant during cardiac operations instead of heparin: successful for aortic valve replacement in man. J Thorac Cardiovasc Surg 1995; 110: 265-7. 
10 Vanholder R, Camez A, Veys N, Van Loo A, Dhondt $A M$, Ringoir $S$. Pharmacokinetics of recombinant hirudin in hemodialyzed end-stage renal failure patients. Thromb Haemost 1997; 77: 650-5. 